\title{
Vascular Complication in Adolescents With Diabetes Mellitus
}

\author{
Lara E. Graves ${ }^{1 *}$ and Kim C. Donaghue ${ }^{1,2}$ \\ ${ }^{1}$ Institute of Endocrinology and Diabetes, The Children's Hospital at Westmead, Westmead, NSW, Australia, ${ }^{2}$ Discipline of \\ Child and Adolescent Health, Children's Hospital at Westmead Clinical School, University of Sydney, Westmead, NSW, \\ Australia
}

Diabetes mellitus is becoming more prevalent and even with new advancements which improve glycaemic control, complications of diabetes are common. Vascular complications of diabetes include the microvascular complications: retinopathy, nephropathy, and peripheral and autonomic neuropathy. Macrovascular complications are also common in patients with diabetes and arguably more concerning as they confer a high mortality risk yet are sometimes under-treated. Risk factors for diabetes complications start to occur in childhood and adolescents and some youths may be diagnosed with complications before transition to adult care. This article discusses the prevalence, risk factors, screening, and treatment recommendations for vascular complications in children and adolescents with diabetes.

\section{OPEN ACCESS}

Edited by:

Francesco Chiarelli,

Università degli Studi G. d'Annunzio

Chieti e Pescara, Italy

Reviewed by:

Jian Zhou,

Chinese Academy of Sciences

(CAS), China

Stefano Zucchini,

Sant'Orsola-Malpighi Polyclinic, Italy

*Correspondence:

Lara E. Graves

lara.graves@health.nsw.gov.au

Specialty section:

This article was submitted to

Pediatric Endocrinology,

a section of the journal

Frontiers in Endocrinology

Received: 31 March 2020

Accepted: 11 May 2020

Published: 09 June 2020

Citation:

Graves LE and Donaghue KC (2020) Vascular Complication in Adolescents

With Diabetes Mellitus.

Front. Endocrinol. 11:370.

doi: 10.3389/fendo.2020.00370
Keywords: diabetes complications, microvascular, macrovascular, nephropathy, neuropathy, retinopathy

\section{INTRODUCTION}

Type 1 diabetes is becoming more prevalent and subclinical diabetes complications are common (1-3). While new advancements have improved glycaemic control and variability and reduced hypoglycaemic unawareness (4), long term complications are still an ongoing burden for patients with diabetes and 1 in 3 youths with type 1 diabetes have at least one diabetes complication (3). Microvascular complications are specific to diabetes and include retinopathy, peripheral neuropathy, autonomic neuropathy and nephropathy (5). The cells in the retina, nerves and renal glomeruli are unable to down-regulate glucose uptake, and in the presence of hyperglycaemia, this leads to an overproduction of superoxide in the mitochondria resulting in oxidative stress (5). Macrovascular complications are not specific to diabetes; however people with diabetes have accelerated atherosclerosis and a higher risk of macrovascular disease than the general population (5). More recently, microvascular complications appear to be decreasing in prevalence when compared with historical data (6), perhaps due in part to the advent of modern diabetes technology. Despite this, some risk factors for macrovascular disease such as obesity and hypertension are increasing (6) and there is a high rate of markers of inflammation associated with atherosclerosis in youth with diabetes (7). In this article we discuss the prevalence, risk factors, screening and treatment recommendations for vascular complications in children with type 1 diabetes. While this article focuses on type 1 diabetes, type 2 diabetes will also be discussed briefly as the prevalence of type 2 diabetes is also increasing in young people, and complications develop at a younger age (8), and may comprise a far greater proportion of the pediatric diabetes clinic in the future.

\section{THE VASCULAR COMPLICATIONS OF DIABETES}

\section{Retinopathy}

Diabetes is the leading cause of new cases of blindness among adults aged 18-64 years (9). Diabetic eye disease encompasses diabetic retinopathy, macular oedema, cataract and glaucoma 
(5). Diabetic retinopathy is a microvascular complication of diabetes and is classified as mild-to-moderate non-proliferative, severe non-proliferative and proliferative. Severe nonproliferative and proliferative disease is vision threatening (10). Mild-to-moderate non-proliferative retinopathy is characterized by microaneurysms, retinal hemorrhages, ischemia, and microinfarction (cotton wool spots), protein and lipid leakage (hard exudates), intraretinal microvascular abnormalities and venular dilation and tortuosity. When there is vascular obstruction, increased number of retinal hemorrhages and microaneurysms with marked venous abnormalities, this is considered severe non-proliferative retinopathy. Proliferative retinopathy is characterized by neovascularisation in either the retina or posterior vitreous space (10). Progression of disease may be asymptomatic, as demonstrated in the case report (Figure 1). The presence of hard exudates with microaneurysms and blot hemorrhages within one disc diameter of the centre of the macular defines diabetic macular oedema (11). Clinically significant macular oedema has been traditionally defined as retinal thickening or hard exudate that involves or is within $500 \mu \mathrm{m}$ of the fovea (12).

\section{Neuropathy}

The most common type of diabetic neuropathy is peripheral neuropathy (diabetic sensorimotor polyneuropathy) but may also involve other parts of the somatic and autonomic nervous systems. In peripheral neuropathy, the sensory function is affected first followed by motor impairment. Patients may feel numbness and this may progress to pain (13).

Autonomic neuropathy may affect many systems including cardiovascular, urogenital or gastrointestinal and may present as orthostatic hypotension, exercise intolerance, resting tachycardia or bradycardia, reduced heart rate variability, gastroparesis, diarrhea, fecal or urinary incontinence, constipation, bladder paresis, and erectile dysfunction $(14,15)$. Loss of heart rate variability due to cardiovascular autonomic neuropathy may increase the risk of severe hypoglycaemia due to impairment of hypoglycaemia awareness (16). Cardiovascular manifestations can indicate sympathetic overdrive and loss of parasympathetic tone (16).

\section{Nephropathy}

Diabetic nephropathy occurs due to interactions between multiple factors including increased systemic and intraglomerular pressure, activation of the renin-angiotensin aldosterone system, activation of vascular endothelial growth factor, and from hyperglycaemia due to oxidative stress, renal polyol formation and accumulation of advanced glycation end products (17). This results in increasing proteinuria, glomerulosclerosis and eventually tubulointerstitial fibrosis (17). Albuminuria was formerly known as microalbuminuria. It is now generally defined based on the albumin-to-creatinine ratio. A ratio of $2.5-25 \mathrm{mg} / \mathrm{mmol}(30-300 \mathrm{mg} / \mathrm{g})$ in males or a ratio of $3.5-25 \mathrm{mg} / \mathrm{mmol}(42-300 \mathrm{mg} / \mathrm{g})$ in females defines albuminuria (10). Ratio levels above these ranges define proteinuria (10). The stages of diabetic nephropathy progress from renal hypertrophy, albuminuria (subclinical nephropathy), proteinuria (overt nephropathy), impairment of glomerular filtration rate (GFR) and finally to end-stage kidney disease (ESKD) $(18,19)$. Albuminuria is a risk factor for diabetic nephropathy, cardiovascular disease, cardiac autonomic dysfunction and mortality $(5,13,20)$.

\section{Macrovascular}

Macrovascular disease affects the coronary, cerebral and peripheral arterial vasculature. Patients with diabetes are at a higher risk of macrovascular disease than the general population and diabetes contributes to earlier mortality from cardiac disease. The duration of diabetes confers higher risk. The risk of coronary heart disease and acute myocardial infarction is 30 times increased in patients diagnosed with type 1 diabetes under the age of 10 years (21). Cardiac disease in type 1 diabetes is contributed to by accelerated atherosclerosis, cardiac autonomic neuropathy and intrinsic diabetic cardiomyopathy (22). Atherosclerosis acceleration is thought to be due to hyperglycaemia, glycation and oxidative stress causing endothelial dysfunction (22). It has been shown that youth with diabetes have higher levels of

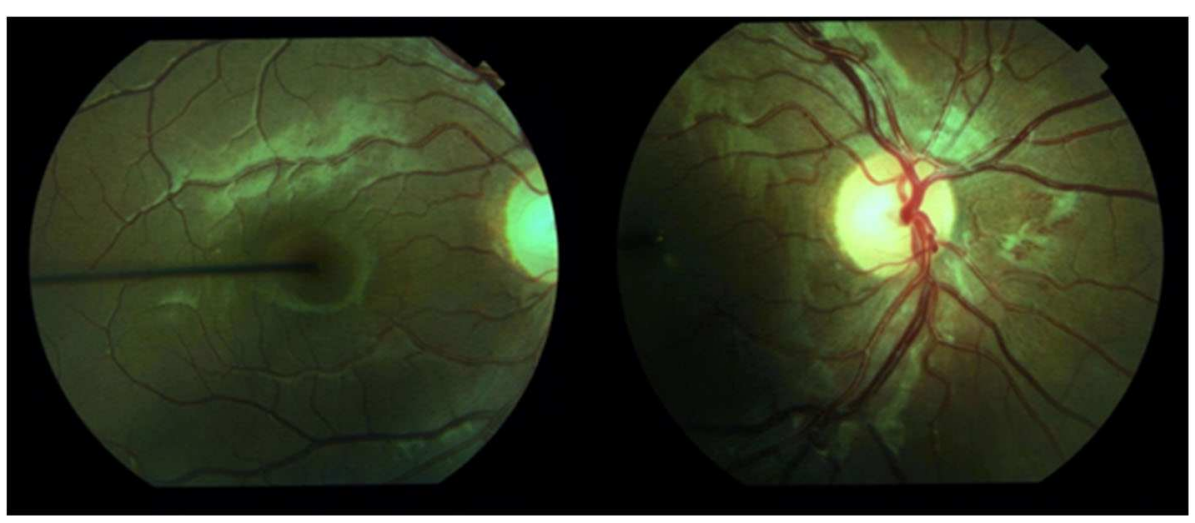

FIGURE 1 | Retinal photography demonstrating proliferative retinopathy in a 15-year-old girl with 12 years diabetes duration and poor metabolic control. This had rapidly progressed from minimal retinopathy documented 2 years before. 
inflammatory biomarkers than their healthy peers, and that those with type 2 diabetes have higher inflammatory levels than those with type 1 diabetes (7).

Diabetic cardiomyopathy is when ventricular dysfunction occurs in patients with diabetes in the absence of coronary artery atherosclerosis and hypertension (22). Diabetic cardiomyopathy is caused by a combination of biochemical disturbances, impaired energy utilization, myocardial fibrosis, small vessel disease, cardiac autonomic neuropathy and insulin resistance (23). This can lead to diastolic and systolic dysfunction, which may present as shortness of breath or exercise intolerance (23). Diabetic cardiomyopathy may lead to diastolic heart failure (23). Otherwise healthy adolescents with type 1 diabetes have been shown to already have reduced exercise capacity and reduced stroke volume during exercise when compared to controls without diabetes (24). Functional cardiac changes occurred even after a relatively short disease duration mean of 6 years (24).

\section{PREVALENCE OF VASCULAR COMPLICATIONS IN ADOLESCENTS WITH DIABETES}

Diabetes complications may develop in young people. Retinopathy is more common in young people with type 1 diabetes than type 2 diabetes, whereas albuminuria and hypertension are more common in young people with type 2 diabetes (25). In a group of 11-17 year old patients who had had type 1 diabetes for 2-5 years, early retinopathy was present in $9 \%$, albuminuria was present in 3\% and there was a peripheral nerve abnormality in $16 \%$ when measured by thermal and vibration thresholds (26). In our institution we had documented a reduction in retinopathy over two decades (1990-2009) in 12 - to 20-year old patients with duration greater than five years (27), but this has plateaued since that report. Indeed, one female patient from our institute has subsequently required laser therapy before the age of 16 years due to proliferative retinopathy (Figure 1). In New Zealand between 2003 and 2016 there has been a decrease in microvascular complications with an increase in obesity and hypertension and no change in the prevalence of dyslipidaemia (6). However another New Zealand study found that in adolescents transitioning from pediatric to adult services between 2006 and 20016 there was no difference in the prevalence of albuminuria or hypertension over the 10 year period reported (28). A summary of the reported prevalence of diabetes complications in young people with type 1 diabetes is presented in Table 1. There is no standard definition of autonomic neuropathy and there is no recommended screening protocol, so the true prevalence is unclear (15).

Atherosclerosis starts in childhood and subclinical cardiovascular disease may be present in youth within 10 years of diagnosis with type 1 diabetes (34). The leading cause of morbidity and mortality in adults with type 1 diabetes is cardiovascular disease (35-38). Those diagnosed with diabetes under the age of 10 years have increased loss of life years and the risk of coronary artery disease and acute myocardial infarction is 30 times increased compared with those diagnosed with diabetes between ages 26-30 years (21). The first cardiovascular events occurred in the third decade of life for patients diagnosed with type 1 or type 2 diabetes at a young age (38). In a retrospective cohort of patients diagnosed with diabetes aged $15-30$ years, $6 \%$ had evidence of macrovascular disease (38). Increased arterial stiffness independently predicts all-cause and cardiovascular mortality in adults with type 1 diabetes (39). Pulse wave velocity (PWV) is a measure of arterial stiffness, and there was a significant increase in PWV in youth with type 1 diabetes over a 5 year period (33). Atherosclerosis is associated with inflammation and biomarkers inflammatory markers (40). A cohort of patients with diabetes with a mean age of 15.6 years, had higher levels of biomarkers of inflammation than their healthy peers, particularly the subgroup with type 2 diabetes, compared with type 1 diabetes, and the overall rates of obesity were higher than that of the general population (7).

Young-onset type 2 diabetes confers a higher risk phenotype with greater mortality, more diabetes complications and more cardiovascular risk factors. The prevalence of type 2 diabetes in youth is increasing (41-43) and it is expected that diabetes complications in youth with type 2 diabetes will become an increasing burden as type 2 diabetes is associated with a higher rate of diabetes complications (43). Youth who have been diagnosed with type 2 diabetes for 1.8 years have similar rates of diabetes complications as youth who have had type 1 diabetes for 8.1 years (7). Youth with type 2 diabetes have a more rapid deterioration of beta cell function than the phenotype that develops in later adulthood (41). Obesity is an important contribution to insulin resistance seen in type 2 diabetes, and obesity itself is also associated with other metabolic risks (41). Complications of diabetes are often present at diagnosis of type 2. Within 2 years of diagnosis, the TODAY study found that adolescents aged 10-17 years already had evidence of diabetes complications or risk factors, including hypertension (13.6\%), albuminuria (13\%), low HDL level (79.8\%), and hypertriglyceridemia (10.2\%) (44). In this cohort there was a rapid rise in hypertension (12-34\%) and albuminuria (6-17\%) over the mean 4-year follow-up period (45). More recently, it was shown in a group of youth with type 2 diabetes with a mean age of 15.1 years and a mean duration of type 2 diabetes of 1.8 years $72 \%$ had evidence of any complication of diabetes. This included hypertension (19\%), albuminuria (19\%), heart rate variability abnormalities (54\%), peripheral nerve abnormalities (19\%), retinopathy (7\%), and abnormal lipid profile (48\%)(7). In a retrospective cohort of patients who had developed type 2 diabetes at a relatively young age (between ages 15 and 30 years), there is significant mortality excess when compared to patients who developed type 1 diabetes at a similar age: $11 \%$ mortality in patients with type 2 diabetes versus $6.8 \%$ mortality in patients with type 1 diabetes over median observation period $>20$ years, with more cardiovascular-attributable deaths in type 2 diabetes (50 vs. $30 \%$ ) (38).

\section{RISK FACTORS FOR DIABETES COMPLICATIONS}

Diabetes duration is the biggest risk factor for albuminuria and retinopathy (46) and is also a risk factor for peripheral 
TABLE 1 | Epidemiology of complications of type 1 diabetes in children and adolescents.

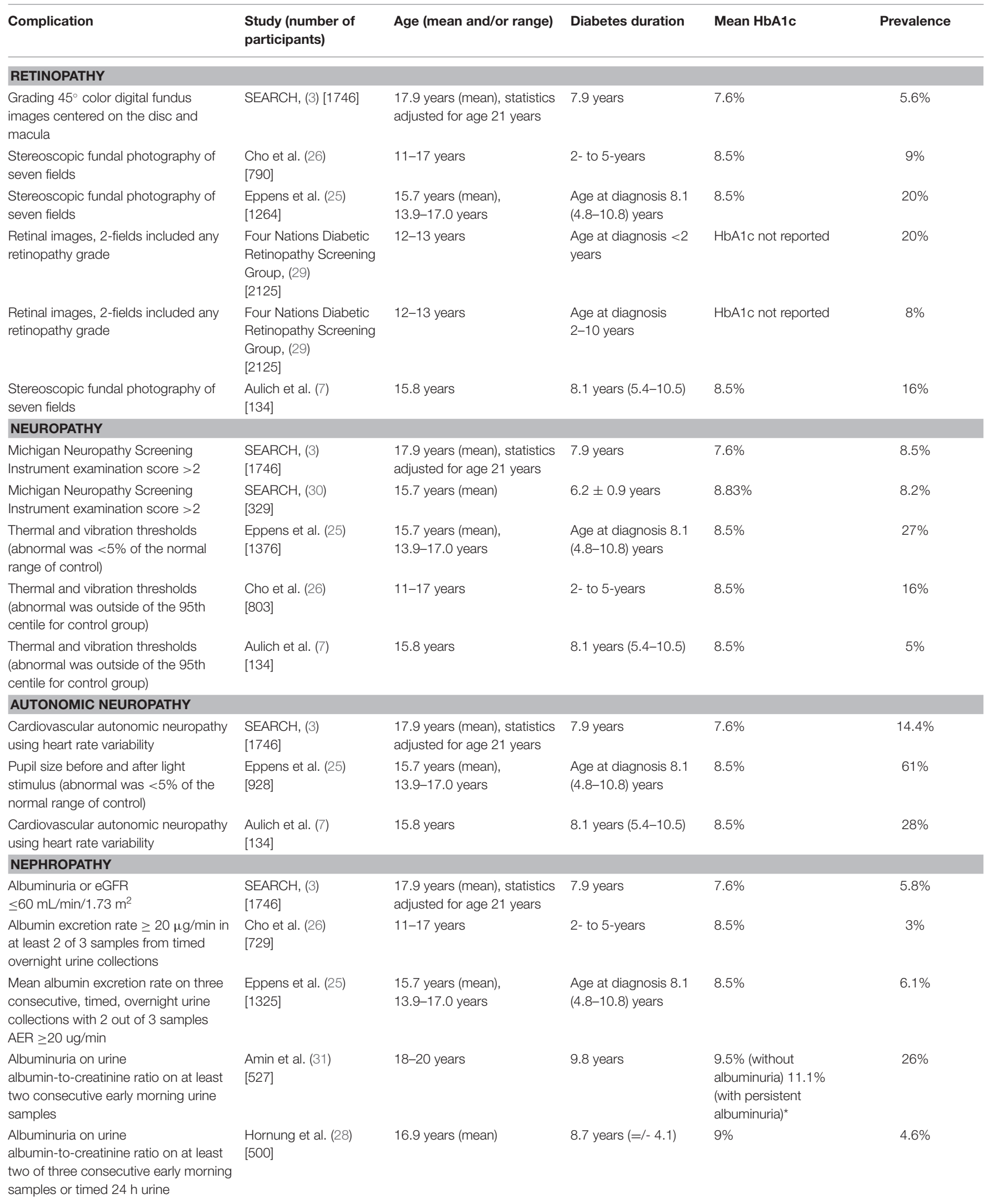


TABLE 1 | Continued

\begin{tabular}{|c|c|c|c|c|c|}
\hline Complication & $\begin{array}{l}\text { Study (number of } \\
\text { participants) }\end{array}$ & Age (mean and/or range) & Diabetes duration & Mean HbA1c & Prevalence \\
\hline $\begin{array}{l}\text { Albuminuria on urine } \\
\text { albumin-to-creatinine ratio on at least } \\
\text { two of three consecutive early morning } \\
\text { samples or timed } 24 \text { h urine }\end{array}$ & $\begin{array}{l}\text { T1D Exchange Clinic } \\
\text { Network, (32) } \\
\text { [7549] }\end{array}$ & $13.8 \pm 3.5$ years & $6.5 \pm 7$ years & $8.4 \%$ & $4.3 \%$ \\
\hline $\begin{array}{l}\text { Albuminuria on urine } \\
\text { albumin-to-creatinine ratio on at least } \\
\text { two of three consecutive early morning } \\
\text { samples or timed } 24 \text { h urine }\end{array}$ & $\begin{array}{l}\text { Aulich et al. (7) } \\
\text { [134] }\end{array}$ & 15.8 years & 8.1 years $(5.4-10.5)$ & $8.5 \%$ & $1 \%$ \\
\hline \multicolumn{6}{|l|}{ HYPERTENSION } \\
\hline & $\begin{array}{l}\text { SEARCH, (3) } \\
{[1746]}\end{array}$ & $\begin{array}{l}17.9 \text { years (mean), statistics } \\
\text { adjusted for age } 21 \text { years }\end{array}$ & 7.9 years & $7.6 \%$ & $10.1 \%$ \\
\hline & $\begin{array}{l}\text { Eppens et al. (25) } \\
\text { [1393] }\end{array}$ & $\begin{array}{l}15.7 \text { years (mean), } \\
13.9-17.0 \text { years }\end{array}$ & $\begin{array}{l}\text { Age at diagnosis } 8.1 \\
(4.8-10.8) \text { years }\end{array}$ & $8.5 \%$ & $16 \%$ \\
\hline \multicolumn{6}{|l|}{ MACRO-VASCULAR } \\
\hline Pulse wave velocity (arterial stiffness) & $\begin{array}{l}\text { SEARCH, (33) } \\
\text { [298] }\end{array}$ & 19.2 years (mean) & 4.8 years & $8.9 \%$ & $\begin{array}{l}\text { Significant increase of } \\
0.145 \mathrm{~m} / \mathrm{s} / \text { year in PWV }\end{array}$ \\
\hline Arterial stiffness & $\begin{array}{l}\text { SEARCH, (3) } \\
{[1746]}\end{array}$ & $\begin{array}{l}17.9 \text { years (mean), statistics } \\
\text { adjusted for age } 21 \text { years }\end{array}$ & 7.9 years & $7.6 \%$ & $11.6 \%$ \\
\hline Abnormal non-fasting lipid profile & $\begin{array}{l}\text { Aulich et al. (7) } \\
\text { [134] }\end{array}$ & 15.8 years & 8.1 years $(5.4-10.5)$ & $8.5 \%$ & $14 \%$ \\
\hline \multicolumn{6}{|l|}{ DIABETIC CARDIOMYOPATHY } \\
\hline $\begin{array}{l}\text { Functional aerobic capacity and } \\
\text { cardiac MRI }\end{array}$ & $\begin{array}{l}\text { Gusso et al. (24) } \\
\text { [53] }\end{array}$ & 15.6 years (mean) & $6 \pm 4$ years & $8.68 \%$ & $\begin{array}{c}10 \% \text { decreased } \\
\text { maximal exercise } \\
\text { capacity compared } \\
\text { with healthy } \\
\text { age-matched controls. } \\
\text { Reduced stroke volume } \\
\text { in patients with type } 1 \\
\text { diabetes. Increased } \\
\text { systolic function at rest } \\
\text { but not during exercise }\end{array}$ \\
\hline
\end{tabular}

"HbA1C for entire cohort not provided. HbA1C provided for subgroups.

neuropathy and macrovascular disease $(13,21)$. Other risk factors for micro and macrovascular disease include young age at diagnosis, higher $\mathrm{HbAlc}$, higher blood pressure and socioeconomic disadvantage $(13,21,27,32,47)$. There is a higher risk of progression of retinal disease in adolescents than in adults (48). The reason behind this is unclear but may be associated with the difficult in achieving glycaemic targets in this life period (49).

Lifestyle factors (such as smoking or poor exercise and diet), obesity, and dyslipidaemia are risk factors for peripheral neuropathy and macrovascular disease $(13,21)$. The presence of hypertension, diabetic kidney disease, insulin resistance or severe diabetic retinopathy are also risk factors for cardiovascular disease $(21,50)$. Furthermore depression (36) and hypoglycaemia (51) may also confer risk.

Youth with type 1 diabetes have a higher prevalence of dyslipidaemia (52), and there appears to be some sort of qualitative or functional abnormalities in lipoproteins in type 1 diabetes, which is more atherogenic (22). Dyslipidaemia is thought to be present in $48-80 \%$ of youth with type 2 diabetes within 2 years of diagnosis $(7,44)$.

Hypertension is a risk factor for microvascular complications and is also a major risk factor for macrovascular disease. Youth with type 1 diabetes have a higher prevalence of hypertension compared with their peers (53). For children aged 1-13 years, stage 1 hypertension is defined as " $\geq 95$ th percentile to $<95$ th percentile $+12 \mathrm{mmHg}$, or 130/80-139/89 $\mathrm{mm} \mathrm{Hg}$ (whichever is lower)" and stage 2 hypertension is defined as " $\geq 95$ th percentile $+12 \mathrm{~mm} \mathrm{Hg}$, or $\geq 140 / 90 \mathrm{~mm} \mathrm{Hg}$ (whichever is lower)". For children 13 years and over stage 1 is 130/80-139/89 mm Hg and stage $2 \geq 140 / 90 \mathrm{~mm} \mathrm{Hg}$ (54). It is confirmed by demonstration of elevated blood pressure on 3 separate occasions and may require $24 \mathrm{~h}$ ambulatory monitoring for confirmation (10, 55, 56). Normative data for blood pressure based on normal-weight children is available (54).

Obesity is a risk factor for both microvascular and macrovascular complications of diabetes. There are higher rates 
of overweight and obesity in youth with type 1 diabetes than their healthy peers (57-59), and BMI in youth may increase further overtime, particularly in girls (60). Albuminuria was associated with lower BMI in patients with type 1 diabetes under the age of 20 years (32). While causation was not examined, one might postulate that this could be due to poor weight gain due to relative insulin deficiency from under-dosing in patients with elevated HbAlc and poor adherence to therapy. Obese patients with diabetes have higher levels of inflammatory markers relative to other weight categories, and may have increased rates of diabetes complications (7).

Sustained hyperglycaemia is associated with diabetes complications and strict glycaemic control reduces both microvascular and macrovascular complications of diabetes $(61,62)$. It has been shown that an increasing HbA1c trajectory is associated with higher BMI, lower linear growth, use of insulin injection therapy and severe hypoglycaemic episodes (63), and poor glycaemic control early in life is associated with microvascular disease (64). Perhaps the HbAlc trajectory, not just the value, may also define risk of vascular complications and thus impact our approach.

The development and use of newer technology such as continuous glucose monitoring has provided detailed information about glucose handling in individual patients. The role of glycaemic variability in the development of complications is unclear $(65,66)$ and while it is recommended that the HbA1c target is $<7 \%(67,68)$, this may not be the only useful measure of complications risk. Thus both HbAclc and "time in range" should be used together when devising treatment goals (69). Continuous subcutaneous insulin infusions using an insulin pump may reduce the risk of complications such as retinopathy and peripheral neuropathy (70). While it has been shown that the use of insulin pump therapy in some cohorts has been associated with improved glycaemic control $(63,71)$, diabetes technology has not necessarily been associated with a sustained improvement in glycaemic control or reduction in complications (72). Few studies have examined glucose variability using continuous glucose monitoring and diabetes complications as the widespread availability of continuous glucose monitoring is relatively recent. It is proposed that intermittent hyperglycaemia confers even greater oxidative stress than sustained hyperglycaemia, but long term studies looking at the glucose variability detected by continuous glucose monitoring and vascular complications are lacking $(66,73)$.

Microvascular disease has improved in a New Zealand cohort when compared with historical data, even in the absence of improvement in glycaemic control (6). Although this study did not address causation, perhaps reduction in glycaemic variability through continuous glucose monitoring has improved complications risk, without an obvious change to HbAlc. Despite an increase in the use of insulin pumps and continuous glucose monitoring in the US, the mean HbAlc in adolescents and young adults with type 1 diabetes has increased (72). Barriers to the use of diabetes technology in the United States may include non-English speaking background and ethnicity (74). Improving glycaemic control is not just related to the availability of technology but requires a multidisciplinary team approach which includes the patient and their family in management decisions (56). When a child and their parent manage the child's diabetes together, they are more likely to meet glycaemic targets (56).

When diabetes is diagnosed in childhood or adolescence, type 2 diabetes confers a higher risk for diabetic kidney disease, retinopathy and peripheral neuropathy than that for type 1 diabetes, but complications are frequent in both groups (3).

\section{DIABETES COMPLICATIONS SCREENING}

The first signs of complications may appear during puberty and this is a critical time for the lifetime risk of diabetes (46). Risk factors should be considered at every visit (56) and at a minimum, blood pressure should be measured at least annually (10).

Regular screening for diabetic retinopathy has been recommended since the 1990s due to the asymptomatic progression to vision-threatening disease $(61,75-77)$. It is recommended that screening should commence from age 11 years after diabetes has been present for 2-5 years. Screening should be performed by an optometrist of ophthalmologist and should include a dilated and comprehensive eye examination. Current guidelines recommend eye screening should take place every 2 years in patients with good glycaemic control $(10,56)$, however more or less often may be appropriate depending on the individual clinical situation $(78,79)$.

Screening for albuminuria should commence from age 11 years after diabetes has been present for 2-5 years using three separate first morning urine samples. A positive result is considered if there is an abnormal urine albumin-to-creatinine ratio in 2 or more of the 3 samples. Screening should occur annually $(10,35,56)$.

It is recommended that screening for peripheral neuropathy commences from age 11 years after diabetes has been present for $2-5$ years and should be repeated annually $(10,56)$. Screening involves examining the foot with inspection and proprioceptive, vibratory and monofilament sensation should be assessed (56). Autonomic neuropathy is not generally screened for as there is no recommended screening technique available (10), but research methods can include measurement of heart rate for tachycardia, and reduced heart rate variability as a proxy for autonomic dysfunction (15).

Screening for dyslipidaemia should commence from 11 years of age, regardless of the duration of diabetes (10). This should not occur in the acute period shortly after diagnosis. Screening should commence at 2 years of age if there is family history significant for either hypercholesterolaemia or early cardiovascular death $(10,56)$. It is appropriate to screen with a non-fasting blood lipid profile, and if this is abnormal then a fasting profile should be performed $(10,56)$.

\section{TREATMENT OF VASCULAR COMPLICATIONS IN ADOLESCENTS}

\section{Retinopathy}

Diabetic retinopathy may regress with improved glycaemic control but care must be taken with this as rapid improvement can actually lead to deterioration of retinopathy (10). The 
progression of retinopathy may be slowed with early use of angiotensin converting enzyme (ACE) inhibitors in adults, and this may be effective even when a patient does not have hypertension (80). However, this effect is yet to be demonstrated in adolescents (81).

Laser photocoagulation or antivascular endothelial growth factor (VEGF) intravitreal injections are required in the treatment of vision-threatening disease (10). Anti-VEGF may be preferred due to the risk of visual field reduction and night blindness associated with laser therapy (82). Anti-VEGF may be more effective prior to the development of proliferative disease (83), and hence early diagnosis is important. Fenofibrate has been used to reduce the need for laser treatment in adults with type 2 diabetes and the mechanism does not seem to be related to the effect on the plasma lipid concentration (84).

Surgery may be required if there is persistent vitreal hemorrhage or if lens extraction is required due to cataract $(5,10)$.

\section{Lifestyle Measures}

The first steps in management of hypertension or dyslipidaemia, are lifestyle measures to optimize body habitus and exercise tolerance and improvement in glycaemic control $(10,85)$. The use of dietary adjuncts such as plant sterols could be considered in the presence of dyslipidaemia (86). If lifestyle measures including diet and exercise are optimized for 3-6 months and there is persistence of hypertension or dyslipidaemia, then pharmacotherapy should be considered (10, $54,56)$. There is often therapeutic inertia to introduce further appropriate treatments in youth (36), but early intervention is imperative and treatment that is indicated should not be withheld.

\section{Anti-hypertensives}

Hypertension and albuminuria may be considered surrogate markers of diabetic kidney disease. ACE inhibitors have been shown to decrease albuminuria in children even in the absence of hypertension and should be used to treat children with albuminuria to prevent progression to proteinuria $(56,87)$. With tight glycaemic control and the use of ACE inhibitors or angiotensin receptor blockers (ARB), albuminuria can improve (14). Hypertension may also be treated with ACE inhibitors, ARB, calcium channel blockers or thiazide diuretic $(10,54$, 56 ), however if concomitant albuminuria is present, treatment with an ACE inhibitor or ARB is recommended. There is no specific recommendation for type of ACE inhibitor and many are appropriate for pediatric use including benazepril, captopril, enalapril, fosinopril or lisinopril (54).

\section{REFERENCES}

1. Dabelea D. Diabetes in youth-looking backwards to inform the future: Kelly West Award Lecture 2017. Diabetes Care. (2018) 41:233-40. doi: 10.2337/dci17-0031

2. Hamman RF, Bell RA, Dabelea D, D'Agostino RB, Jr., Dolan L, et al. The SEARCH for diabetes in youth study: Rationale, findings, and

\section{Statins}

Statins effectively treat dyslipidaemia in adolescents with type 1 diabetes $(10,56,81)$. If the LDL cholesterol remains greater than $3.4 \mathrm{mmol} / \mathrm{L}$ despite lifestyle measures, statins should be considered from the age of 11 years. The use of statins is not approved for children under 10 years (56). Atorvastatin, lovastatin or pravastatin have been trialed in children and adolescents and shown to be safe and effective in the treatment of dyslipidaemia $(81,88-90)$. Dyslipidaemia that is being treated with pharmacotherapy should be monitored with fasted lipid profiles, targeting a fasting LDL cholesterol of $<2.6 \mathrm{mmol} / \mathrm{L}$ (56).

\section{Smoking}

In addition to management of hypertension and dyslipidaemia, young people should be counseled to avoid or cease smoking cigarettes, as smoking avoidance helps prevent both microvascular and macrovascular complications (56).

\section{Metformin}

Metformin is recommended in the treatment of type 2 diabetes in youth (91). It may also help reduce the BMI and insulin requirements in overweight youth with type 1 diabetes $(92,93)$. Metformin may have an additional role in the cardiovascular health of patients with diabetes. Metformin was shown to improve vascular smooth muscle function independently of any improvement in glycaemic control and insulin sensitivity in adolescents with type 1 diabetes (94). In patients aged 12 and 21 years with type 1 diabetes metformin use showed improvement in MRI-derived measures of aortic and carotid vascular health (93).

\section{CONCLUSION}

Vascular complications of diabetes are common in youth with diabetes, and infer a high morbidity and mortality risk (2, 3). Prevention is critical, by targeting risk factors such as glycaemic control, adiposity, hypertension, dyslipidaemia and life style factors. Improvements may be achieved using appropriate diabetes technology, a multidisciplinary team approach and health education $(61,62,65)$. Screening for complications is crucial as at-risk adolescents must be identified and treatment commenced before irreversible changes occur.

\section{AUTHOR CONTRIBUTIONS}

LG and KD researched the scientific literature, wrote the review and edited the review before submission. LG prepared the tables.

future directions. Diabetes Care. (2014) 37:3336-44.d doi: 10.2337/dc140574

3. Dabelea D, Stafford JM, Mayer-Davis EJ, D'Agostino R, Jr., Dolan L, et al. Association of type 1 diabetes vs. type 2 diabetes diagnosed during childhood and adolescence with complications during teenage years and young adulthood. JAMA. (2017) 317:825-35. doi: 10.1001/jama.2017. 0686 
4. O'Connell PJ, Hawthorne WJ, Holmes-Walker DJ, Nankivell BJ, Gunton JE, Patel AT, et al. Clinical islet transplantation in type 1 diabetes mellitus: Results of Australia's first trial. Med J Aust. (2006) 184:2215. doi: 10.5694/j.1326-5377.2006.tb00206.x

5. Katsarou A, Gudbjornsdottir S, Rawshani A, Dabelea D, Bonifacio E, Anderson BJ, et al. Type 1 diabetes mellitus. Nat Rev Dis Primers. (2017) 3:17016. doi: 10.1038/nrdp.2017.16

6. Sandhu SK, Corbett VM, Chepulis L, Goldsmith J, Joseph P, Fraser SK, et al. The prevalence of microvascular complications in Waikato children and youth with type 1 diabetes has reduced since 2003. N Z Med J. (2020) 133:3544.

7. Aulich J, Cho YH, Januszewski AS, Craig ME, Selvadurai H, Wiegand $\mathrm{S}$, et al. Associations between circulating inflammatory markers, diabetes type and complications in youth. Pediatr Diabetes. (2019) 20:111827. doi: $10.1111 /$ pedi.12913

8. Dart AB, Martens PJ, Rigatto C, Brownell MD, Dean HJ, Sellers EA. Earlier onset of complications in youth with type 2 diabetes. Diabetes Care. (2014) 37:436-43. doi: 10.2337/dc13-0954

9. Centers for Disease Control Prevention. National Diabetes Statistics Report, 2020. Atlanta, GA: Centers for Disease Control Prevention, US Dept of Health and Human Services. (2020). Available online at: https://www.cdc.gov/ diabetes/pdfs/data/statistics/national-diabetes-statistics-report.pdf.

10. Donaghue KC, Marcovecchio ML, Wadwa RP, Chew EY, Wong TY, Calliari LE, et al. ISPAD Clinical Practice Consensus Guidelines 2018: Microvascular and macrovascular complications in children and adolescents. Pediatr Diabetes. (2018) 19 Suppl 27:262-74. doi: 10.1111/pedi.12742

11. Lee R, Wong TY, Sabanayagam C. Epidemiology of diabetic retinopathy, diabetic macular edema and related vision loss. Eye Vis (Lond). (2015) 2:17. doi: 10.1186/s40662-015-0026-2

12. Early Treatment Diabetic Retinopathy Study design and baseline patient characteristics. ETDRS report number 7. Ophthalmology. (1991). $98(5$ Suppl):741-56. doi: 10.1016/S0161-6420(13)38009-9

13. Jaiswal M, Divers J, Dabelea D, Isom S, Bell RA, Martin CL, et al. Prevalence of and risk factors for diabetic peripheral neuropathy in youth with type 1 and type 2 diabetes: SEARCH for diabetes in youth study. Diabetes Care. (2017) 40:1226-32. doi: 10.2337/dc17-0179

14. Perkins BA, Ficociello LH, Silva KH, Finkelstein DM, Warram JH, Krolewski AS. Regression of microalbuminuria in type 1 diabetes. $N$ Engl J Med. (2003) 348:2285-93. doi: 10.1056/NEJMoa021835

15. Tang M, Donaghue KC, Cho YH, Craig ME. Autonomic neuropathy in young people with type 1 diabetes: a systematic review. Pediatr Diabetes. (2013) 14:239-48. doi: 10.1111/pedi.12039

16. da Silva T, Rolim L, de Camargo Sallum Filho C, Zimmermann LM, Malerbi F, Dib S. Impaired awareness of hypoglycemia is associated with progressive loss of heart rate variability in patients with type 1 diabetes. Diabetol Metabol Syndr. (2015) 7(Suppl 1):A63. doi: 10.1186/1758-5996-7-S1-A63

17. Soldatos G, Cooper ME. Diabetic nephropathy: important pathophysiologic mechanisms. Diabetes Res Clin Pract. (2008) 82 Suppl 1:S75-9. doi: 10.1016/j.diabres.2008.09.042

18. Mogensen CE. Microalbuminuria in prediction and prevention of diabetic nephropathy in insulin-dependent diabetes mellitus patients. $J$ Diabetes Compl. (1995) 9:337-49. doi: 10.1016/1056-8727(95)80036-E

19. Mogensen CE. Drug treatment for hypertensive patients in special situations: diabetes and hypertension. Clin Exp Hypertens. (1999) 21:895906. doi: $10.3109 / 10641969909061018$

20. Rossing P, Hougaard P, Borch-Johnsen K, Parving HH. Predictors of mortality in insulin dependent diabetes: 10 year observational follow up study. BMJ. (1996) 313:779-84. doi: 10.1136/bmj.313.7060.779

21. Rawshani A, Sattar N, Franzen S, Rawshani A, Hattersley AT, Svensson AM, et al. Excess mortality and cardiovascular disease in young adults with type 1 diabetes in relation to age at onset: a nationwide, register-based cohort study. Lancet. (2018) 392:477-86. doi: 10.1016/S0140-6736(18)31506-X

22. Retnakaran R, Zinman B. Type 1 diabetes, hyperglycaemia, and the heart. Lancet. (2008) 371:1790-9. doi: 10.1016/S0140-6736(08)60767-9

23. Fang ZY, Prins JB, Marwick TH. Diabetic cardiomyopathy: evidence, mechanisms, and therapeutic implications. Endocr Rev. (2004) 25:54367. doi: 10.1210/er.2003-0012
24. Gusso S, Pinto TE, Baldi JC, Robinson E, Cutfield WS, Hofman PL. Diastolic function is reduced in adolescents with type 1 diabetes in response to exercise. Diabetes Care. (2012) 35:2089-94. doi: 10.2337/dc11-2331

25. Eppens MC, Craig ME, Cusumano J, Hing S, Chan AK, Howard NJ, et al. Prevalence of diabetes complications in adolescents with type 2 compared with type 1 diabetes. Diabetes Care. (2006) 29:1300-6. doi: 10.2337/dc05-2470

26. Cho YH, Craig ME, Hing S, Gallego PH, Poon M, Chan A, et al. Microvascular complications assessment in adolescents with 2- to 5-yr duration of type 1 diabetes from 1990 to (2006). Pediatr Diabetes. (2011) 12:682-9. doi: 10.1111/j.1399-5448.2011.00762.x

27. Downie E, Craig ME, Hing S, Cusumano J, Chan AK, Donaghue KC. Continued reduction in the prevalence of retinopathy in adolescents with type 1 diabetes: role of insulin therapy and glycemic control. Diabetes Care. (2011) 34:2368-73. doi: $10.2337 / \mathrm{dc} 11-0102$

28. Hornung RJ, Reed PW, Mouat F, Jefferies C, Gunn AJ, Hofman PL. Angiotensin-converting enzyme-inhibitor therapy in adolescents with type 1 diabetes in a regional cohort: Auckland, New Zealand from 2006 to 2016. J Paediatr Child Health. (2018) 54:493-8. doi: 10.1111/jpc.13814

29. Scanlon PH, Stratton IM, Bachmann MO, Jones C, Leese GP, Four Nations Diabetic Retinopathy Screening Study G. Risk of diabetic retinopathy at first screen in children at 12 and 13 years of age. Diabet Med. (2016) 33:16558. doi: 10.1111/dme.13263

30. Jaiswal M, Lauer A, Martin CL, Bell RA, Divers J, Dabelea D, et al. Peripheral neuropathy in adolescents and young adults with type 1 and type 2 diabetes from the SEARCH for Diabetes in Youth follow-up cohort: a pilot study. Diabetes Care. (2013) 36:3903-8. doi: 10.2337/dc13-1213

31. Amin R, Widmer B, Prevost AT, Schwarze P, Cooper J, Edge J, et al. Risk of microalbuminuria and progression to macroalbuminuria in a cohort with childhood onset type 1 diabetes: prospective observational study. British Medical Journal. (2008) 336:697-701. doi: 10.1136/bmj.39478.378241.BE

32. Daniels M, DuBose SN, Maahs DM, Beck RW, Fox LA, Gubitosi-Klug R, et al. Factors associated with microalbuminuria in 7,549 children and adolescents with type 1 diabetes in the T1D Exchange clinic registry. Diabetes Care. (2013) 36:2639-45. doi: 10.2337/dc12-2192

33. Dabelea D, Talton JW, D’Agostino R, Jr., Wadwa RP, Urbina EM, et al. Cardiovascular risk factors are associated with increased arterial stiffness in youth with type 1 diabetes: the SEARCH CVD study. Diabetes Care. (2013) 36:3938-43. doi: $10.2337 / \mathrm{dc} 13-0851$

34. Singh TP, Groehn H, Kazmers A. Vascular function and carotid intimalmedial thickness in children with insulin-dependent diabetes mellitus. J Am Coll Cardiol. (2003) 41:661-5. doi: 10.1016/S0735-1097(02)02894-2

35. Chiang JL, Maahs DM, Garvey KC, Hood KK, Laffel LM, Weinzimer SA, et al. Type 1 diabetes in children and adolescents: a position statement by the American Diabetes Association. Diabetes Care. (2018) 41:202644. doi: $10.2337 /$ dci18-0023

36. Bjornstad P, Donaghue KC, Maahs DM. Macrovascular disease and risk factors in youth with type 1 diabetes: time to be more attentive to treatment? Lancet Diabetes Endocrinol. (2018) 6:809-20. doi: 10.1016/S2213-8587(18) 30035-4

37. Krolewski AS, Kosinski EJ, Warram JH, Leland OS, Busick EJ, Asmal AC, et al. Magnitude and determinants of coronary artery disease in juvenileonset, insulin-dependent diabetes mellitus. Am J Cardiol. (1987) 59:7505. doi: 10.1016/0002-9149(87)91086-1

38. Constantino MI, Molyneaux L, Limacher-Gisler F, Al-Saeed A, Luo C, Wu T, et al. Long-term complications and mortality in young-onset diabetes: type 2 diabetes is more hazardous and lethal than type 1 diabetes. Diabetes Care. (2013) 36:3863-9. doi: 10.2337/dc12-2455

39. Cruickshank K, Riste L, Anderson SG, Wright JS, Dunn G, Gosling RG. Aortic pulse-wave velocity and its relationship to mortality in diabetes and glucose intolerance: an integrated index of vascular function? Circulation. (2002) 106:2085-90. doi: 10.1161/01.CIR.0000033824.02722.F7

40. Berliner JA, Navab M, Fogelman AM, Frank JS, Demer LL, Edwards PA, et al. Atherosclerosis: basic mechanisms. Oxidation, inflammation, and genetics. Circulation. (1995) 91:2488-96. doi: 10.1161/01.CIR.91.9.2488

41. D'Adamo E, Caprio S. Type 2 diabetes in youth: epidemiology and pathophysiology. Diabetes Care. (2011) 34 Suppl 2:S1615. doi: $10.2337 / \mathrm{dc} 11-\mathrm{s} 212$ 
42. Pinhas-Hamiel O, Zeitler P. The global spread of type 2 diabetes mellitus in children and adolescents. J Pediatr. (2005) 146:693-700. doi: 10.1016/j.jpeds.2004.12.042

43. Jensen ET, Dabelea D. Type 2 Diabetes in Youth: New Lessons from the SEARCH Study. Curr Diab Rep. (2018) 18:36. doi: 10.1007/s11892-018-0997-1

44. Copeland KC, Zeitler P, Geffner M, Guandalini C, Higgins J, Hirst K, et al. Characteristics of adolescents and youth with recent-onset type 2 diabetes: the TODAY cohort at baseline. J Clin Endocrinol Metab. (2011) 96:15967. doi: $10.1210 /$ jc.2010-1642

45. Today Study Group. Rapid rise in hypertension and nephropathy in youth with type 2 diabetes: the TODAY clinical trial. Diabetes Care. (2013) 36:173541. doi: $10.2337 / \mathrm{dc} 12-2420$

46. Dunger DB. Banting Memorial Lecture 2016. Reducing lifetime risk of complications in adolescents with type 1 diabetes. Diabet Med. (2017) 34:4606. doi: 10.1111/dme.13299

47. Gallego PH, Craig ME, Hing S, Donaghue KC. Role of blood pressure in development of early retinopathy in adolescents with type 1 diabetes: prospective cohort study. BMJ. (2008) 337:a918. doi: 10.1136/bmj.a918

48. Hietala K, Harjutsalo V, Forsblom C, Summanen P, Groop PH, FinnDiane Study G. Age at onset and the risk of proliferative retinopathy in type 1 diabetes. Diabetes Care. (2010) 33:1315-9. doi: 10.2337/dc09-2278

49. White NH, Cleary PA, Dahms W, Goldstein D, Malone J, Tamborlane WV, et al. Beneficial effects of intensive therapy of diabetes during adolescence: outcomes after the conclusion of the Diabetes Control and Complications Trial (DCCT). J Pediatr. (2001) 139:804-12. doi: 10.1067/mpd.2001.118887

50. Pongrac Barlovic D, Harjutsalo V, Gordin D, Kallio M, Forsblom C, King $\mathrm{G}$, et al. The association of severe diabetic retinopathy with cardiovascular outcomes in long-standing type 1 diabetes: a longitudinal follow-up. Diabetes Care. (2018) 41:2487-94. doi: 10.2337/dc18-0476

51. Pena AS, Couper JJ, Harrington J, Gent R, Fairchild J, Tham E, et al. Hypoglycemia, but not glucose variability, relates to vascular function in children with type 1 diabetes. Diabetes Technol Ther. (2012) 14:45762. doi: 10.1089/dia.2011.0229

52. Schwab KO, Doerfer J, Marg W, Schober E, Holl RW, Initiative DPVS, et al. Characterization of 33488 children and adolescents with type 1 diabetes based on the gender-specific increase of cardiovascular risk factors. Pediatr Diabetes. (2010) 11:357-63. doi: 10.1111/j.1399-5448.2010.00665.x

53. Knerr I, Dost A, Lepler R, Raile K, Schober E, Rascher W, et al. Tracking and prediction of arterial blood pressure from childhood to young adulthood in 868 patients with type 1 diabetes: a multicenter longitudinal survey in Germany and Austria. Diabetes Care. (2008) 31:7267. doi: $10.2337 / \mathrm{dc} 07-1392$

54. Flynn JT, Kaelber DC, Baker-Smith CM, Blowey D, Carroll AE, Daniels $\mathrm{SR}$, et al. Clinical practice guideline for screening and management of high blood pressure in children and adolescents. Pediatrics. (2017) 140:e20171904. doi: 10.1542/peds.2017-3035

55. Soergel M, Kirschstein M, Busch C, Danne T, Gellermann J, Holl R, et al. Oscillometric twenty-four-hour ambulatory blood pressure values in healthy children and adolescents: a multicenter trial including 1141 subjects. J Pediatr. (1997) 130:178-84. doi: 10.1016/S0022-3476(97)70340-8

56. American Diabetes A. 13. Children and adolescents: standards of medical care in diabetes-2019. Diabetes Care. (2019) 42(Suppl 1):S148-S64. doi: 10.2337/dc19-S013

57. DuBose SN, Hermann JM, Tamborlane WV, Beck RW, Dost A, DiMeglio LA, et al. Obesity in youth with type 1 diabetes in Germany, Austria, and the United States. J Pediatr. (2015) 167:627-32 e1-4. doi: 10.1016/j.jpeds.2015.05.046

58. Redondo MJ, Foster NC, Libman IM, Mehta SN, Hathway JM, Bethin $\mathrm{KE}$, et al. Prevalence of cardiovascular risk factors in youth with type 1 diabetes and elevated body mass index. Acta Diabetol. (2016) 53:2717. doi: 10.1007/s00592-015-0785-1

59. Phelan H, Clapin H, Bruns L, Cameron FJ, Cotterill AM, Couper JJ, et al. The Australasian Diabetes Data Network: first national audit of children and adolescents with type 1 diabetes. Med J Aust. (2017) 206:1215. doi: 10.5694/mja16.00737

60. Phelan H, Foster NC, Schwandt A, Couper JJ, Willi S, Kroschwald P, et al. Longitudinal trajectories of BMI z-score: an international comparison of
11,513 Australian, American and German/Austrian/Luxembourgian youth with type 1 diabetes. Pediatr Obes. (2020) 15:e12582. doi: 10.1111/ijpo.12582

61. Nathan DM, Genuth S, Lachin J, Cleary P, Crofford O, Davis M, et al. The effect of intensive treatment of diabetes on the development and progression of long-term complications in insulin-dependent diabetes mellitus. $\mathrm{N} \mathrm{Engl} \mathrm{J}$ Med. (1993) 329:977-86. doi: 10.1056/NEJM199309303291401

62. Stratton IM, Adler AI, Neil HA, Matthews DR, Manley SE, Cull CA, et al. Association of glycaemia with macrovascular and microvascular complications of type 2 diabetes (UKPDS 35): prospective observational study. BMJ. (2000) 321:405-12. doi: 10.1136/bmj.321.7258.405

63. Clements MA, Schwandt A, Donaghue KC, Miller K, Luck U, Couper JJ, et al. Five heterogeneous HbAlc trajectories from childhood to adulthood in youth with type 1 diabetes from three different continents: a group-based modeling approach. Pediatr Diabetes. (2019) 20:920-31. doi: 10.1111/pedi.12907

64. Writing Team for the Diabetes C, Complications Trial/Epidemiology of Diabetes I, Complications Research G. Effect of intensive therapy on the microvascular complications of type 1 diabetes mellitus. JAMA. (2002) 287:2563-9. doi: 10.1001/jama.287.19.2563

65. Monnier L, Colette C, Owens D. The glycemic triumvirate and diabetic complications: is the whole greater than the sum of its component parts? Diabetes Res Clin Pract. (2012) 95:303-11. doi: 10.1016/j.diabres.2011.10.014

66. Ceriello A, Monnier L, Owens D. Glycaemic variability in diabetes: clinical and therapeutic implications. Lancet Diabetes Endocrinol. (2019) 7:22130. doi: 10.1016/S2213-8587(18)30136-0

67. DiMeglio LA, Acerini CL, Codner E, Craig ME, Hofer SE, Pillay K, et al. ISPAD Clinical Practice Consensus Guidelines 2018: glycemic control targets and glucose monitoring for children, adolescents, and young adults with diabetes. Pediatr Diabetes. (2018) 19 Suppl 27:105-14. doi: 10.1111/pedi.12737

68. The National Institute for Health and Care Excellence (NICE) Guideline 18: Diabetes (type 1 and type 2) in Children and Young People: Diagnosis and Management. London (2015). Available online at: http://nice.org.uk/ guidance/ng18.

69. Danne T, Nimri R, Battelino T, Bergenstal RM, Close KL, DeVries JH, et al. International consensus on use of continuous glucose monitoring. Diabetes Care. (2017) 40:1631-40. doi: 10.2337/dc17-1600

70. Zabeen B, Craig ME, Virk SA, Pryke A, Chan AK, Cho YH, et al. Insulin pump therapy is associated with lower rates of retinopathy and peripheral nerve abnormality. PLoS One. (2016) 11:e0153033. doi: 10.1371/journal.pone.0153033

71. Mair C, Wulaningsih W, Jeyam A, McGurnaghan S, Blackbourn L, Kennon $\mathrm{B}$, et al. Glycaemic control trends in people with type 1 diabetes in Scotland 2004-2016. Diabetologia. (2019) 62:1375-84. doi: 10.1007/s00125-019-4900-7

72. Foster NC, Beck RW, Miller KM, Clements MA, Rickels MR, DiMeglio LA, et al. State of type 1 diabetes management and outcomes from the tld exchange in 2016-2018. Diabetes Technol Ther. (2019) 21:6672. doi: 10.1089/dia.2018.0384

73. Jung HS. Clinical implications of glucose variability: chronic complications of diabetes. Endocrinol Metab (Seoul). (2015) 30:167-74. doi: 10.3803/EnM.2015.30.2.167

74. O'Connor MR, Carlin K, Coker T, Zierler B, Pihoker C. Disparities in insulin pump therapy persist in youth with type 1 diabetes despite rising overall pump use rates. J Pediatr Nurs. (2019) 44:16-21. doi: 10.1016/j.pedn.2018.10.005

75. Kernell A, Dedorsson I, Johansson B, Wickstrom CP, Ludvigsson J, Tuvemo T, et al. Prevalence of diabetic retinopathy in children and adolescents with IDDM. A population-based multicentre study. Diabetologia. (1997) 40:30710. doi: $10.1007 / \mathrm{s} 001250050679$

76. Diabetes Control and Complications Trial Research Group. Effect of intensive diabetes treatment on the development and progression of long-term complications in adolescents with insulin-dependent diabetes mellitus: diabetes control and complications trial. J Pediatr. (1994) 125:17788. doi: 10.1016/S0022-3476(94)70190-3

77. Retinopathy Working Party. A protocol for screening for diabetic retinopathy in Europe. Diabet Med. (1991). 8:2637. doi: 10.1111/j.1464-5491.1991.tb01583.x

78. Group DER, Nathan DM, Bebu I, Hainsworth D, Klein R, Tamborlane W, et al. Frequency of evidence-based screening for retinopathy in type 1 diabetes. $N$ Engl J Med. (2017) 376:1507-16. doi: 10.1056/NEJMoa1612836 
79. Gubitosi-Klug RA, Bebu I, White NH, Malone J, Miller R, Lorenzi GM, et al. Screening eye exams in youth with type 1 diabetes under 18 years of age: once may be enough? Pediatr Diabetes. (2019) 20:743-9. doi: 10.1111/pedi.12877

80. Mauer M, Zinman B, Gardiner R, Suissa S, Sinaiko A, Strand T, et al. Renal and retinal effects of enalapril and losartan in type 1 diabetes. $N$ Engl J Med. (2009) 361:40-51. doi: 10.1056/NEJMoa0808400

81. Marcovecchio ML, Chiesa ST, Bond S, Daneman D, Dawson S, Donaghue KC, et al. ACE inhibitors and statins in adolescents with type 1 diabetes. $N$ Engl J Med. (2017) 377:1733-45. doi: 10.1056/NEJMoa1703518

82. Aiello LM. Perspectives on diabetic retinopathy. Am J Ophthalmol. (2003) 136:122-35. doi: 10.1016/S0002-9394(03)00219-8

83. Ip MS, Domalpally A, Sun JK, Ehrlich JS. Long-term effects of therapy with ranibizumab on diabetic retinopathy severity and baseline risk factors for worsening retinopathy. Ophthalmology. (2015) 122:367-74. doi: 10.1016/j.ophtha.2014.08.048

84. Keech A, Mitchell P, Summanen P, O'Day J, Davis T, Moffitt M, et al. Effect of fenofibrate on the need for laser treatment for diabetic retinopathy (FIELD study): a randomised controlled trial. Lancet. (2007) 370:168797. doi: 10.1016/S0140-6736(07)61607-9

85. Maahs DM, Daniels SR, de Ferranti SD, Dichek HL, Flynn J, Goldstein BI, et al. Cardiovascular disease risk factors in youth with diabetes mellitus: a scientific statement from the American Heart Association. Circulation. (2014) 130:1532-58. doi: 10.1161/CIR.0000000000000094

86. Expert Panel on Integrated Guidelines for Cardiovascular H, Risk Reduction in C, Adolescents, National Heart L, Blood I. Expert panel on integrated guidelines for cardiovascular health and risk reduction in children and adolescents: summary report. Pediatrics. (2011) 128 Suppl 5:S21356. doi: 10.1542/peds.2009-2107C

87. Cook J, Daneman D, Spino M, Sochett E, Perlman K, Balfe JW. Angiotensin converting enzyme inhibitor therapy to decrease microalbuminuria in normotensive children with insulin-dependent diabetes mellitus. J Pediatr. (1990) 117(1 Pt 1):39-45. doi: 10.1016/S0022-3476(05)82441-2

88. Langslet G, Breazna A, Drogari E. A 3-year study of atorvastatin in children and adolescents with heterozygous familial hypercholesterolemia. J Clin Lipidol. (2016) 10:1153-62 e3. doi: 10.1016/j.jacl.2016.05.010

89. Stein EA, Illingworth DR, Kwiterovich PO, Jr., Liacouras CA, Siimes MA, et al. Efficacy and safety of lovastatin in adolescent males with heterozygous familial hypercholesterolemia: a randomized controlled trial. JAMA. (1999) 281:137-44. doi: 10.1001/jama.281.2.137
90. Wiegman A, Hutten BA, de Groot E, Rodenburg J, Bakker HD, Buller $\mathrm{HR}$, et al. Efficacy and safety of statin therapy in children with familial hypercholesterolemia: a randomized controlled trial. JAMA. (2004) 292:3317. doi: $10.1001 /$ jama.292.3.331

91. Zeitler P, Arslanian S, Fu J, Pinhas-Hamiel O, Reinehr T, Tandon N, et al. ISPAD Clinical Practice Consensus Guidelines 2018: Type 2 diabetes mellitus in youth. Pediatr Diabetes. (2018) 19 Suppl 27:28-46. doi: 10.1111/pedi. 12719

92. Libman IM, Miller KM, DiMeglio LA, Bethin KE, Katz ML, Shah A, et al. Effect of metformin added to insulin on glycemic control among overweight/obese adolescents with type 1 diabetes: a randomized clinical trial. JAMA. (2015) 314:2241-50. doi: 10.1001/jama.2015. 16174

93. Bjornstad P, Schafer M, Truong U, Cree-Green M, Pyle L, Baumgartner A, et al. Metformin improves insulin sensitivity and vascular health in youth with type 1 diabetes mellitus. Circulation. (2018) 138:2895-907. doi: 10.1161/CIRCULATIONAHA.118.0 35525

94. Anderson JJA, Couper JJ, Giles LC, Leggett CE, Gent R, Coppin $B$, et al. Effect of metformin on vascular function in children with type 1 diabetes: a 12-month randomized controlled trial. $J$ Clin Endocrinol Metab. (2017) 102:4448-56. doi: 10.1210/jc.201700781

Conflict of Interest: KD receives research support from the Australian National Health and Medical Research Council and Diabetes Australia, and her institution has received research support from JDRF and Medtronic. She has received speaker fees from Eli Lilly.

The remaining author declares that the research was conducted in the absence of any commercial or financial relationships that could be construed as a potential conflict of interest.

Copyright (c) 2020 Graves and Donaghue. This is an open-access article distributed under the terms of the Creative Commons Attribution License (CC BY). The use, distribution or reproduction in other forums is permitted, provided the original author(s) and the copyright owner(s) are credited and that the original publication in this journal is cited, in accordance with accepted academic practice. No use, distribution or reproduction is permitted which does not comply with these terms. 